\title{
Temnomastax hamus Rehn \& Rehn, 1942 (Orthoptera: Eumastacidae: Temnomastacinae): First record for Brazilian wetland
}

\author{
Daniela Santos M. Silva ${ }^{1 *}$, Renan da Silva Olivier ${ }^{2}$, Adriane Vieira Souza ${ }^{1}$, Daiane Oliveira ${ }^{1}$, Marcos \\ G. Lhano ${ }^{1}$ and Marinêz I. Marques ${ }^{3}$ \\ 1 Universidade Federal do Recôncavo da Bahia (UFRB), Centro de Ciências Agrárias, Ambientais e Biológicas (CCAAB), Laboratório de Ecologia e \\ Taxonomia de Insetos (LETI). Rua Rui Barbosa, 710 - 44380-000, Cruz das Almas, BA, Brazil. \\ 2 Universidade Federal de Mato Grosso do Sul (UFMS), Centro de Ciências Biológicas e da Saúde (CCBS), Laboratório de Zoologia. Cidade \\ Universitária, 79070-900, Campo Grande, MS, Brazil. \\ 3 Universidade Federal de Mato Grosso (UFMT), Programa de Pós-Graduação em Ecologia e Conservação da Biodiversidade. Av. Fernando Corrêa \\ da Costa, nº 2367 - Bairro Boa Esperança, 78060-900, Cuiabá, MT, Brazil. \\ * Corresponding author. E-mail: danielasantos.biology@gmail.com
}

\begin{abstract}
Two specimens of Temnomastax hamus Rehn \& Rehn, 1942 were collected at the Advanced Base of Studies at the Universidade Federal de Mato Grosso in Poconé, Mato Grosso, Pantanal. These new records extend the known distribution of the species to include the Brazilian Pantanal.
\end{abstract}

DOI: $10.15560 / 10.6 .1504$

Eumastacids are small arboreal grasshoppers commonly known as 'monkey grasshoppers' or 'saltamontes payaso' which are found predominantly in tropical regions near forests (Liebermann 1955; Nickle and Walker 2011). The Temnomastacinae subfamily occurs exclusively in South America and it has been recorded in dry regions of Brazil, Paraguay and Bolivia (Descamps 1973a). This group is composed of two genera: Eutemnomastax, which has four species restricted to northeastern Brazil, and Temnomastax, which has seven species distributed throughout the Brazilian savannah (Cerrado) biome (Descamps 1982; Eades et al. 2013).

The species Temnomastax hamus Rehn \& Rehn, 1942 is characterized by its medium size, lanky body, brachypterous wings, subrostrate subgenital plate, and very curved cercus, which has the appearance of a hook, as its name suggests (the Latin. hāmus, 'hook') (Figure 1). T. hamus has previously been recorded to occur in the Brazilian states of Minas Gerais, São Paulo, Mato Grosso, Mato Grosso do Sul, Goiás, and in the central region of
Paraguay (Rehn and Rehn 1942; Descamps 1973b; 1982). The type material was collected in November 1919 by members of the Cornell University expedition with R.G. Harris in Lassance, Minas Gerais, Brazil. This material is housed at the Academy of Natural Sciences of Philadelphia (ANSP Philadelphia) under the registration number 5625 (Rehn and Rehn 1942).

Two specimens of T. hamus were collected in October 2012 (dry season) in the city of Poconé, Brazilian Pantanal (16³0'3.41" S, 56²4'47.76" W, $130 \mathrm{~m}$ ). The collection occurred during field studies conducted by the Programa de Apoio a Núcleos de Excelência (PRONEX) from the Advanced Base of Studies at the Universidade Federal de Mato Grosso in the Brazilian phytoecological savannah region (Figure 2). The specimens were collected during the day using an entomological net without a special methodological protocol. Afterwards, the specimens were transported to the Laboratory of Insect Ecology and Taxonomy at the Universidade Federal do Recôncavo da Bahia (UFRB). The species was determined using the

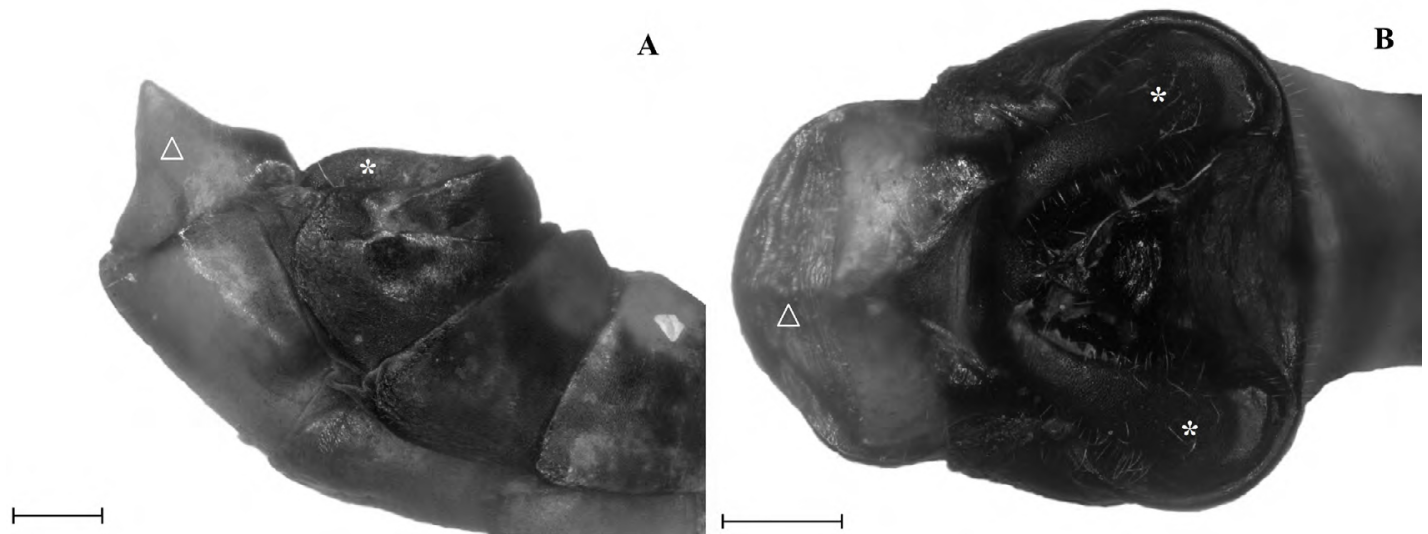

FIGURE 1. External genitalia of Temnomastax hamus; A. lateral view and B. dorsal view. Scale $0.5 \mathrm{~mm}(*$ indicating cercus with hooked form and $\triangle$ subgenital plate). 

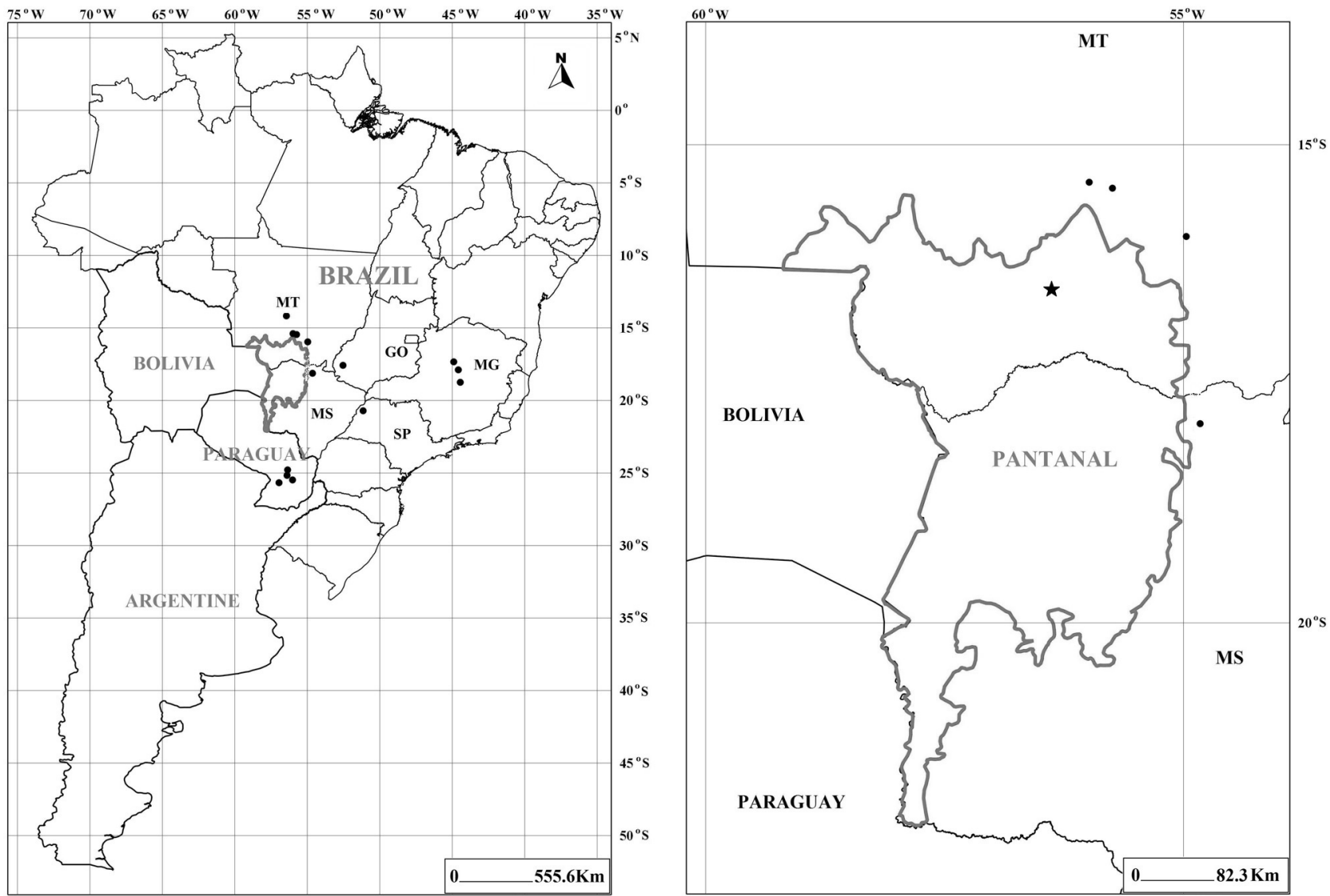

FIGURE 2. In the left, map showing the records (black dots) for the species Temnomastax hamus; in the right, map representing the Pantanal wetlands area with new record for Temnomastax hamus (black star).

following literature: Rehn and Rehn (1942), Rehn and Grant Jr. (1958) and Descamps (1973a). Specimens were measured to the nearest millimeter (Table 1).

No biogeographic data exists for Temnomastax hamus in the Pantanal. The current record is based on just two male specimens of Temnomastax hamus, but is important because it extends the known species distribution to include southeastern and midwestern Brazil and central Paraguay. Based on the relationship of T. hamus with the type of vegetation in which the species has been observed, the species is most likely distributed throughout the Brazilian savannah and possibly across western Paraguay and Bolivia. The Brazilian savannah is floristically similar to the eastern regions of Paraguay and Bolivia, where Chaco vegetation predominates (Spichiger et al. 2006).

Due to the lack of resources at the time when the original work on T. hamus was performed (between 1942 and 1982), the literature on T. hamus understandably lacks records of GPS coordinates and/or elevation of the sites of collection. However, we note that elevation at different sites of collection varies from 750 m (in Mineiros, Goiás, Brazil) to $112 \mathrm{~m}$ (in Carayaó, Paraguay). The specimens collected in the states of Minas Gerais and Mato Grosso (Chapada dos Guimarães) were found at altitudes higher than 300 m. The specimens collected in Paraguay, São Paulo and Mato Grosso were found at similar altitudes because these localities are mainly in the plain that includes the Brazilian savannah, Pantanal and Chaco, providing support for the proposed species distribution (Table 2).

Approximately $36 \%$ of Pantanal consists of Cerrado vegetation, predominantly of two vegetation types
TABLE 1. Measurements (in mm) of specimens Temnomastax hamus Rehn \& Rehn, 1942.

\begin{tabular}{llll}
\hline SPECIMENS & H.f. & Tg. & P. \\
\hline 0 & 11.81 & 2.79 & 2.10 \\
0 & 11.33 & 2.77 & 2.00 \\
\hline
\end{tabular}

H.f. - hind femur, Tg. - tegmina, P. - pronotum; Unit = mm.

Cerradão (22\%) and cerrado sensu stricto (14\%) (Silva et al. 2000). This biome is experiencing severe loss of diversity due to anthropogenic impact. The biodiversity crisis, coupled with the limited number of Orthoptera taxonomists (Green, 1998), hinders efforts to assess this species in areas where it has been recorded as well as, and more importantly, areas which have not been sampled yet.

The data on T. hamus indicates that it is sympatric to Temnomastax latens, as discovered by Rehn and Rehn in 1942 in Minas Gerais (Rehn and Rehn 1942; Liebermann 1955). This reinforces the importance of species distribution data in order to delimit the co-occurring species. Here, we emphasize the need for empirical data collection on the biological and ecological relationships of the Temnomastacinae species. These new species records are relevant to the development of conservation strategies, since the distribution data of Temnomastax hamus is essential for biogeographic studies.

ACKNOWLEDGMENTS: The authors thank the projects "SISBIOTA Brazil (Edital MCT/ CNPq/MMA/MEC/CAPES/FNDCT and FAPEMIG - Ação Transversal/FAPs \#47/201047/2010, Proc. 563360/2010-0)" and "PRONEX (FAPEMAT/CNPq)" for financial support. In addition, we acknowledge with gratitude: Cesar C. Caceres Encina for his assistance in preparing the distribution map; Ph.D. Fernando Paiva and M.S. Rodrigo 
TABLE 2. Data for all records ever made for the species Temnomastax hamus Rehn \& Rehn, 1942.

\begin{tabular}{|c|c|c|c|c|c|c|}
\hline \multirow{2}{*}{ LOCAL } & \multirow{2}{*}{ DATE } & \multirow{2}{*}{ COLLECTOR } & \multicolumn{3}{|c|}{ AMOUNT } & \multirow[t]{2}{*}{ ALTITUDE $^{4}$} \\
\hline & & & $\hat{0}$ & q & NYMPH & \\
\hline \multicolumn{7}{|l|}{ BRAZIL } \\
\hline \multicolumn{7}{|l|}{ Goiás State } \\
\hline Mineiros & II. $1979^{3}$ & O. Roppa \& B. Silva & 1 & 1 & - & $750 \mathrm{~m}$ \\
\hline \multicolumn{7}{|l|}{ Mato Grosso State } \\
\hline Chapada dos Guimarães & 25.I.1972 & C.Carbonell, M. Descamps \& R. Ronderos & - & 1 & - & $585 \mathrm{~m}$ \\
\hline Chapada dos Guimarães/Cuiabá & 26.I.1972 & C.Carbonell, M. Descamps \& R. Ronderos & 1 & - & 1 & $238 \mathrm{~m}$ \\
\hline Diamantino & II.1978 & B. Silva & - & 1 & - & $269 \mathrm{~m}$ \\
\hline Jaciara & 24.I.1972 & C.Carbonell, M. Descamps \& R. Ronderos & 1 & - & - & $400 \mathrm{~m}$ \\
\hline Poconé ${ }^{1}$ & X.2013 & D. Silva & 2 & - & - & $130 \mathrm{~m}$ \\
\hline \multicolumn{7}{|l|}{ Mato Grosso do Sul State } \\
\hline Pedro Gomes (Córrego Boa Vista) & 23.I.1972 & C.Carbonell, M. Descamps \& R. Ronderos & 7 & 3 & 1 & $290 \mathrm{~m}$ \\
\hline \multicolumn{7}{|l|}{ Minas Gerais State } \\
\hline Curvelo & XI.1977 & O. Roppa & 3 & 3 & - & $670 \mathrm{~m}$ \\
\hline Lassance $^{2}$ & 9-19.XI.1919 & R.G. Harris \& Cornell University Expedition & 2 & - & - & $570 \mathrm{~m}$ \\
\hline Pirapora & 17-23.XI.1976 & M. Descamps & 15 & 29 & - & $510 \mathrm{~m}$ \\
\hline \multicolumn{7}{|l|}{ São Paulo State } \\
\hline Pereira Barreto (Ilha Seca) & 19-26.II.1940 & C.Carbonell, M. Descamps \& R. Ronderos & 1 & 2 & - & $360 \mathrm{~m}$ \\
\hline \multicolumn{7}{|l|}{ PARAGUAY } \\
\hline \multicolumn{7}{|l|}{ San Pedro Departament } \\
\hline Carayaó/Unión & 17.I.1972 & C. Carbonell, M. Descamps \& R. Ronderos & 1 & 4 & - & $129 \mathrm{~m}$ \\
\hline \multicolumn{7}{|l|}{ Caaguazu Departament } \\
\hline Caaguazu & 12.III.1965 & C. Carbonell, A. Mesa \& M.A. Monne & 1 & - & - & $330 \mathrm{~m}$ \\
\hline Carayaó & 18.I.1972 & C. Carbonell, M. Descamps \& R. Ronderos & 2 & 5 & - & $112 \mathrm{~m}$ \\
\hline \multicolumn{7}{|l|}{ Paraguari Departament } \\
\hline Sapucay & 7.III.1966 & C. Carbonell, A. Mesa \& M.A. Monne & 1 & - & - & $175 \mathrm{~m}$ \\
\hline
\end{tabular}

${ }^{1}$ New record for T. hamus; ${ }^{2}$ Location type by Rehn \& Rehn, $1942 ;{ }^{3}$ Last record for T. hamus by Descamps, $1982 ;{ }^{4}$ All previous records to the Poconé were obtained by literature review (Rehn \& Rehn, 1942 and Descamps, 1973b). The altimetry data were obtained through pictures by satellite software Google Earth (2013), based on the smallest geopolitical location provided in the literature already cited; $\mathrm{m}=\mathrm{meters}$.

Aranda for assisting with the pictures; and to Ph.D. Corinna S. Bazelet (Stellenbosch University, Department of Conservation Ecology and Entomology, South Africa) for English review of the manuscript.

\section{LITERATURE CITED}

Descamps, M. 1973a. Révision des Eumastacoidea (Orthoptera) aux échelons des familles et des sous familles (genitalia, répartition, phylogénie). Acrida 2: 161-298.

Descamps, M. 1973b. Diagnoses et signalisations d'Eumastacoidea (Orthoptera). IV. Amerique. Annales de la Société Entomologique de France 9(4): 943-974.

Descamps, M. 1982. Eumastacoidea néotropicaux, diagnoses, signalisations, notes biologiques, II. Bulletin de la Société Entomologique de France 87(5-6): 141-180.

Eades, D.C., Otte D., Cigliano M.M. and Braun H. 2013. Orthoptera Species File. Version 5.0/5.0. Eeletronic database accessible at http:// Orthoptera.SpeciesFile.org. Captured on 05 April 2013.

Google Earth. 2013. Google Earth ${ }^{\text {TM }}$. Version 7.1.1.1888. Accessible at http://www.googleearth.com.br. Captured on 30 July 2013.

Green, S.V.1998. The taxonomic impediment in orthopteran research and conservation. Journal of Insect Conservation 2: 151-159 (doi: 10.1023/A:1009633811789).

Liebermann, J. 1955. Primeira relação sistemática de Acridoideos do Brasil. Memórias do Instituto Osvaldo Cruz 53(2-3-4): 329-344 (doi: 10.1590/S0074-02761955000200011).
Nickle, D.A. and Walker, T.J. 2011. Ordem Orthoptera: Gafanhotos, grilos e esperanças; pp. 211-228, in: C.A. Triplehorn and N.N. Jonnson (ed.). Estudos dos Insetos. Volume I. São Paulo: Editora CENGAGE Learning.

Rehn, J.A.G. and Grant Jr., H.J. 1958. The phallic complex in the subfamilies of New World Eumastacidae and the family Tanaoceridae. Proceedings of the Academy of Natural Sciences of Philadelphia 110: 301-319 (doi: $10.2307 / 4064533)$.

Rehn, J.A.G. and Rehn, J.W.H. 1942. A review of the New World Eumastacinae (Orthoptera, Acrididae): Part II. Proceedings of the Academy of Natural Sciences of Philadelphia 94: 1-88 (doi: 10.2307/4064318).

Silva, M.P, R. Mauro, G. Mourão and M. Coutinho. 2000. Distribuição e quantificação de classes de vegetação do Pantanal através de levantamento aéreo. Revista Brasileira de Botânica 23(2): 143-152 (doi: 10.1590/S0100-84042000000200004).

Spichiger, R., B. Bise, C. Calenge and C. Chatelain. 2006. Biogeography of the Forests of the Paraguay-Paraná Basin; pp. 193-212, in: R.T. Pennington, G.P. Lewis, J.A. Ratter (eds.). Neotropical Savannas and Fry Forests: Diversity, Biogeography, and Conservation. Special volume 69. Boca Raton: CRC Press Taylor \& Francis Group.

RECEIVED: September 2013

ACCEPTED: July 2014

Published online: December 2014

EDITORIAL RESPONSIBILITY: Marcelo Ribeiro Pereira 